\title{
Detail Analysis and Properties of Different Types of Portland Cement
}

\author{
Ms. Nora Zilam Runera \\ AMCRET, Russian \\ orazilamr@mail.ru
}

Abstract

Portland concrete is a powdered that is the dynamic fixing in concrete. It is depicted as the holding material having firm and concrete properties which makes it skilled to join the undeniable improvement materials and structure the compacted get together. In this paper we have looking at changed kinds of Portland concrete.

Keywords: white cement, Portland cement etc.

\section{INTRODUCTION}

It is the essential segment of cement. For gathering, first the unrefined materials got from the source are decreased to fine unit size. Concrete is surrounded when Portland solid makes a paste with water that attaches with sand and rock to cement. These fixings like shale mud iron, etc when warmed at high temperatures structure a stone like substance that is ground into the fine powder that we by and large consider as concrete. As the temperature ascends above $8000 \mathrm{C}$, the progression of head dynamic mixes of Portland solid beginnings. Likewise, the satisfaction of this technique occurs at $1400-16000 \mathrm{C}$. Last thing that we get is PC clinker. A weight driven cement made by finely powdering the clinker made by calcinig to event mix a mix of argillaceous and calcareous materials. 


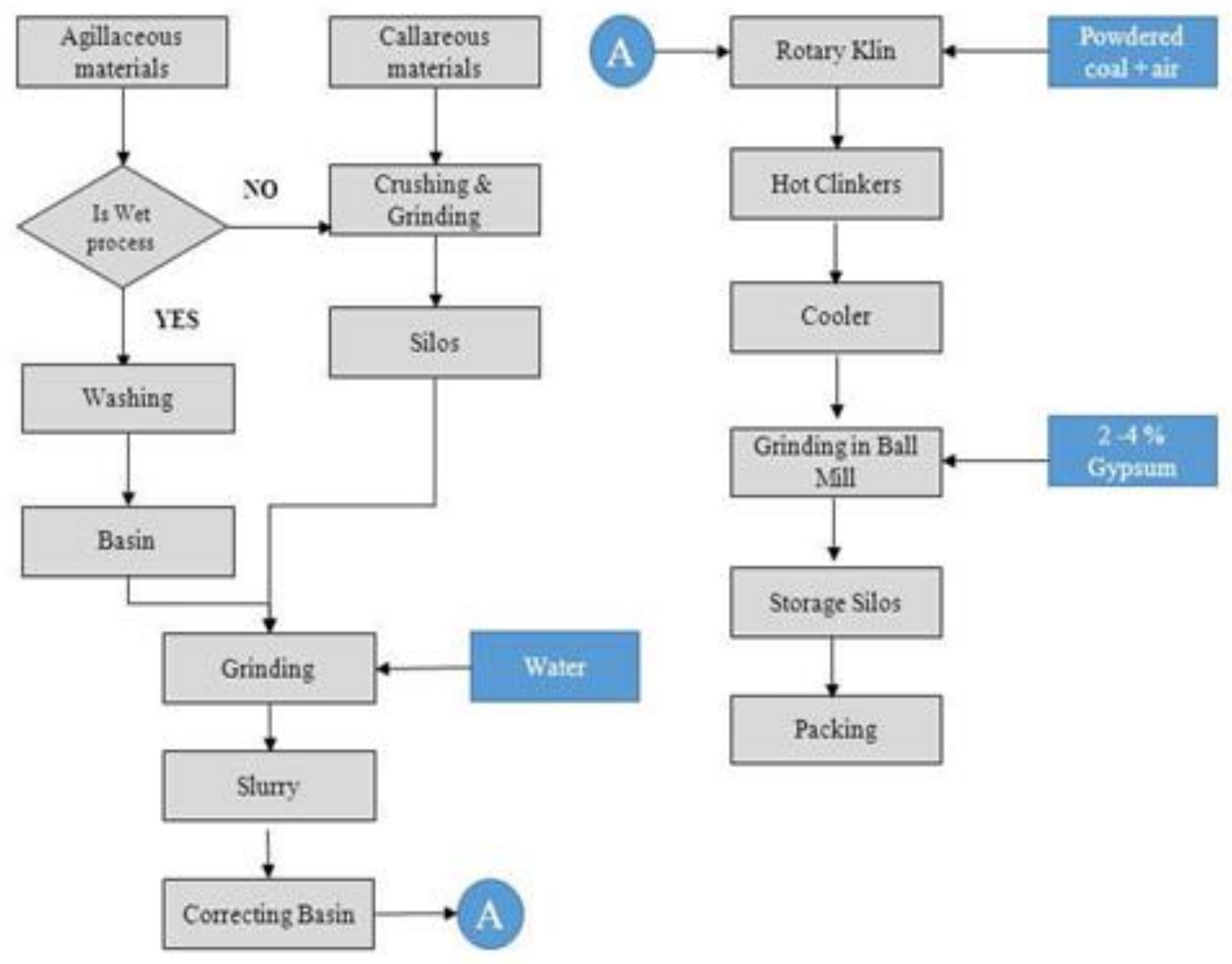

Fig 1: manufacturing process of Portland cement

\section{TYPES OF PORTLAND CEMENT}

Type I: It is also called general purpose cement and it is available in white or dark. The C3S present in this kind of cement is valuable for the quality advancement of the structure. It is utilized for general kind of developments, for example, bridges, pavements, precast units and buildings. It ought to be viewed as a standard material to be utilized on all work here no unordinary conditions or prerequisites are probably going to be encountered prepared mixed cement is typically batched with Type I cement except if some other kind is determined by the buyer.

Type II cement imparts to concrete all the fundamental qualities reachable with Type I cement, in addition to improved resistance from sulfate attack, less generation of heat, to some degree better work capacity, and less tendency to bleed. Type II cement is ground finer than Type I, and it has a to some degree diverse chemical composition. Concrete made with Type II cement will 
show lower early quality than concrete containing Type I cement, yet at a quarter of a year there is no significant distinction in qualities. It is also called moderate sulfate resistance cement. It goes about as a safe for the sulfate assault in the structure because of natural impacts and climatic changes. . It is utilized where the structure materials like soil and water containing more sulfate ions is utilized for the development in light of its sulfate resistant activity. its, significant when cement is cast against soil that has moderate sulfate levels.

Type III is ground better and responds quicker than Type I, so the early quality increases are more noteworthy. Be that as it may, a definitive quality isn't higher than Type I. Concrete made with Type III will have somewhat higher multi day qualities. Type III is accessible in white or gray, yet white Type III is hard to track down in little (not as much as bed) amounts; it frequently must be extraordinary ordered. This cement is the fine cement. As the name infers the quality of the structure is high in quick period. It contains more C3S component. It is used for rapid construction like quick time construction and construction during the cold weather season.

Type IV are utilized in exceptional development applications where high sulfate resistance is required or a low heat of hydration is significant. It is known as low heat of hydration cement and also called slow reacting cement. It structures like dams. This kind of cement is currently uncommon being used.

Type V: It is known as high sulfate resistance cement. It additionally goes about as a sulfate resistant. It contains low amount of C3A . It is utilized in the structures which are subjected of uncovered in high levels of sulfate particles assault from different sources.

White: It is arranged with its shading. It has no C4AF component and low $\mathrm{MgO}$ component. It is utilized for decorative purpose. The properties of White cement are same as the Type I cement.

To accomplish best outcomes, it is prudent to utilize white cement with reasonable fine and coarse aggregates. Further as this cement contains low substance of alkalies it isn't liable to cause staining. It is fabricated from raw materials containing no iron oxide or almost no iron oxide and manganese oxide. Normally China clay is utilized along with lime stone or chalk liberated from impurities. Further to stay away from pollution with coal debris in furnace, oil is utilized as fuel instead of pulverised coal.

The elimination of iron oxide needs higher temperature in furnace to intertwine the raw materials as iron oxide goes about as a flux. To get higher temperature in furnace needs more fuel which isn't economical. Henceforth to drop down the combining temperature, now and then cryolite (sodium aluminum fluoride) is included as a flux. Thus the cost of grinding is higher. Because of higher crushing expense and costly raw materials, make this cement around multiple times costlier than standard Portland cement. To get great shading, generally white cement of rich 
proportions is utilized. The water cement proportion generally isn't received higher than 0.4. Quality of white cement likewise is lower than standard Portland cement.

TABLE 1

\section{CLASSIFICATION OF TYPE OF PORTLAND CEMENT}

\begin{tabular}{l|l|l|l} 
& Classification & Characteristics & Applications \\
\hline Type I & General Purpose & $\begin{array}{l}\text { Fairly high C3S content } \\
\text { for good early strength } \\
\text { development }\end{array}$ & $\begin{array}{l}\text { General construction (most } \\
\text { buildings, bridges, } \\
\text { pavements, precast units, } \\
\text { etc) }\end{array}$ \\
\hline $\begin{array}{l}\text { Type } \\
\text { II }\end{array}$ & $\begin{array}{l}\text { Moderate sulfate } \\
\text { resistance }\end{array}$ & Low C3A content $(<8 \%)$ & $\begin{array}{l}\text { Structures exposed to soil or } \\
\text { water containing sulfate } \\
\text { ions }\end{array}$ \\
\hline $\begin{array}{l}\text { Type } \\
\text { III }\end{array}$ & High early strength & $\begin{array}{l}\text { Ground more finely, may } \\
\text { have slightly more C3S }\end{array}$ & $\begin{array}{l}\text { Rapid construction, cold } \\
\text { weather concreting }\end{array}$ \\
\hline $\begin{array}{l}\text { Type } \\
\text { IV }\end{array}$ & $\begin{array}{l}\text { Low heat of } \\
\text { hydration (slow } \\
\text { reacting) }\end{array}$ & $\begin{array}{l}\text { Low content of C3S } \\
(<50 \%) \text { and C3A }\end{array}$ & $\begin{array}{l}\text { Massive structures such as } \\
\text { dams. Now rare. }\end{array}$ \\
\hline $\begin{array}{l}\text { Type } \\
\text { V }\end{array}$ & $\begin{array}{l}\text { High sulfate } \\
\text { resistance }\end{array}$ & $\begin{array}{l}\text { Very low C3A content } \\
(<5 \%)\end{array}$ & $\begin{array}{l}\text { Structures exposed to high } \\
\text { levels of sulfate ions }\end{array}$ \\
\hline White & White color & No C4AF, low Mg0 & $\begin{array}{l}\text { Decorative (otherwise has } \\
\text { properties similar to Type I) }\end{array}$
\end{tabular}

\section{CONCLUSION}

It is a greenish grey colored powder, made of calcined mixtures of clay and limestone. At the point when mixed in with water turns into a hard and solid structure material. In this paper we have discussed Portland cement concrete that is a hydraulic cement when combined with water, hardens into a solid mass. As a material, Portland cement has been used for well over 175 years and, from an empirical perspective, its behavior is well-understood. 


\section{REFERENCES}

[1] C. M. Hanson, "Concrete: the advanced industrial material of the 21 st century," Metallurgical \& Materials Transactions A, vol. 26, pp. 1321-1341, 1995.

[2] M. Bediako, S. K. Y. Gawu, and A. A. Adjaottor, "Suitability of some Ghanaian mineral admixtures for masonry mortar formulation," Construction and Building Materials, vol. 29, pp. 667-671, 2012.

[3] S. H. Kosmatka, B. Kerkhoff, and W. C. Panarese, Design and Control of Concrete Mixtures, Portland Cement Association,Skokie, Ill, USA, 14th edition, 2002.

[4] M. S. Mamlouk and J. P. Zaniewski, Materials for Civil andConstruction Engineers, Prentice Hall, Upper Saddle River, NJ,USA, 2006.

[5] T. Punmatharith, M. Rachakornkij, A. Imyim, and M.Wecharatana, "Co-processing of grinding sludge as alternative raw material in portland cement clinker production," Journal of Applied Sciences, vol. 10, no. 15, pp. 1525-1535, 2010.

[6] D. N. Huntzinger and T. D. Eatmon, "A life-cycle assessment of Portland cement manufacturing: comparing the traditional process with alternative technologies," Journal of Cleaner Production, vol. 17, no. 7, pp. 668-675, 2009.

[7] F. M. Lea, The Chemistry of Cement and Concrete, Arnold Publishers, London, UK, 3rd edition, 1970.

[8] J. F. Young, S.Mindess, R. J. Gray, andA. Bentur,TheScience andTechnology of Civil Engineering Materials, Prentice-Hall, Upper Saddle River, NJ, USA, 1998.

[9] H. F. W. Taylor, Cement Chemistry, Thomas Telford, London,UK, 2nd edition, 1997.

[10] S. H. Kosmatka and M. L. Wilson, Design and Control of Concrete Mixtures, Portland Cement Association, Stokie, Ill, USA, 2011.

[11] V. Sata, C. Jaturapitakkul, and K. Kiattikomol, "Influence of pozzolan from various by-product materials on mechanical properties of high-strength concrete," Construction and BuildingMaterials, vol. 21, no. 7, pp. 1589-1598, 2007.

[12] A. Neville, Neville on Concrete, ACI, Farmington Hills, Mich, USA, 2003.

[13] R. Fernandez, F. Martirena, and K. L. Scrivener, "The origin of the pozzolanic activity of calcined clay minerals: a comparison between kaolinite, illite and montmorillonite," Cement and

Concrete Research, vol. 41, no. 1, pp. 113-122, 2011.

[14] K. Ganesan, K. Rajagopal, and K. Thangavel, "Evaluation of bagasse ash as supplementary cementitious material," Cement and Concrete Composites, vol. 29, no. 6, pp. 515-524, 2007.

[15] S. Sinthaworn and P. Nimityongskul, "Quick monitoring of pozzolanic reactivity of waste ashes," Waste Management, vol.29, no. 5, pp. 1526-1531, 2009.

[16] J. J. Brooks,M. A.M. Johari, andM.Mazloom, "Effect of admixtures on the setting times of highstrength concrete," Cement and Concrete Composites, vol. 22, no. 4, pp. 293-301, 2000.

[17] X. Fu, Z.Wang,W. Tao et al., "Studies on blended cement with a large amount of fly ash," Cement and Concrete Research, vol. 32,no. 7, pp. 1153-1159, 2002.

[18] E.-H. Kadri, S. Kenai, K. Ezziane, R. Siddique, and G. De Schutter, "Influence of metakaolin and silica fume on the heat of hydration and compressive strength development of mortar," Applied Clay Science, vol. 53, no. 4, pp. 704-708, 2011.

[19] V. Indrawati and A. Manaf, "Mechanical strength of trass as supplementary cementing material," Journal of Physical Science, vol. 92, no. 2, pp. 51-59, 2008. 